\title{
Resistance gradient of black pod disease in cocoa and selection by leaf disk assay
}

Elisa Susilene Lisboa dos Santos ${ }^{1 *}$, Carlos Bernard Moreno Cerqueira-Silva ${ }^{1}$, Didier Clement ${ }^{2}$ and Edna Dora Martins Newman Luz ${ }^{3}$

Received 3 July 2010

Accepted 11 March 2011

\begin{abstract}
To characterize the gradient of resistance to black pod disease experimentally, the leaf disk assay was applied to 217 cocoa genotypes. The parameters time interval, number of leaves evaluated per genotype and distribution of experimental treatments were evaluated. Significant differences between genotypes were found, resulting in the grouping in five homogenous groups $(p<0.01)$. In the assessments with the leaf disk test, five and seven days after inoculation, the F value was highest after seven days, clearly separating the resistant from susceptible genotypes. There was no difference between the clones behavior and the use of more than one box to group the genotypes $(p=0.56)$ and the use of different leaves of the same genotype $(p=0.08)$. The resistance gradient observed indicates variability enough for mapping and cocoa breeding in the population.
\end{abstract}

Key words: genetic mapping, breeding, disease index, Phytophthora palmivora, Theobroma cacao.

\section{INTRODUCTION}

Cacao (Theobroma cacao L.) is a perennial plant whose primary diversity center lies in the Amazon basin (Dias 2001, Bartley 2005). Cacao is mainly produced in the Ivory Coast, Ghana, Cameroon, Indonesia, and Brazil (World Cocoa Foundation 2008). The economic success of cocoa plantations is limited mainly by the occurrence of pathogens that can destroy the production on farms by up to $100 \%$ (Bowers et al. 2001).

Among cacao diseases, black pod (caused by Phytophthora spp.) can be considered the most important, because it occurs in all cocoa-producing countries (Luz and Silva 2001). Of the seven species of Phytophthora that cause black pod in cacao, P. palmivora is the most widely distributed in the world; in Brazil, its occurrence has increased considerably in recent years due to increased rainfall (Luz and Silva 2001).

Among the measures adopted to control this disease are appropriate cultural practices including fungicide application. This practice, although widespread, has the disadvantage of increasing the production costs (Tan and Tan 1990), polluting the environment (Akinnifesi et al. 2006) and being little effective in the field control of black pod if not applied properly (Nyassé et al. 2006). A promising alternative of black pod control, similar to other cacao diseases (Faleiro et al. 2004), is the use of resistant genotypes enriched with genes of morphological and agronomic traits of interest (Nyassé et al. 2003, Pokou et al. 2008).

To identify and characterize the level of black pod resistance in cacao, several methodologies have been

\footnotetext{
${ }^{1}$ Universidade Estadual do Sudoeste da Bahia (UESB), Campus Itapetinga, BR 415, km 3, s/n, 45.700-000, Itapetinga, BA, Brazil. *E-mail: elisalisboa@yahoo.com.br

${ }^{2}$ Centro de Pesquisas do Cacau (CEPEC), Seção de Genética, Rod. Ilhéus-Itabuna, km 22, 45.600-000, Itabuna, BA, Brazil.

${ }^{3}$ CEPEC, Seção de Fitopatologia
} 
developed and refined (Nyassé et al. 1995, Iwaro et al. 2000, Luz et al. 2006). Among these, the leaf disk assay allows a quick and early evaluation of the resistance level, requiring minimum space for the installation of the experiment (Nyassé et al. 1995). The repeatability and reliability of this method are discussed in some papers; a positive correlation between data obtained with the leaf disk assay and natural infection in the field have been reported, calling for a standardization of the test (Nyassé et al. 1995, Nyassé et al. 2002, Tahi et al. 2006a).

Although this test is being used in evaluations of Phytophthora spp. resistance in several countries, there are a few experimental questions that need to be clarified, as the minimum number of leaves per plant and plants per genotype needed to obtain leaf disks for resistance evaluation. The answers to these and other questions are important to standardize this approach for routine use. Additionally, disease indices have been used efficiently in some studies for evaluation of a number of crops (Czermainski 1999, Cerqueira-Silva et al. 2008) and, more recently, for cocoa diseases (Santos et al. 2009).

The purpose of this study was to characterize the resistance gradient of $P$. palmivora and select genotypes from 213 cacao trees of a segregating $F_{2}$ population obtained by self-pollination of the hybrid-clone TSH 516 (selected in Trinidad and Tobago) resulting from a cross between Sca 6 (Amazon Forastero) and ICS 1 (Trinitario), based on the disease index proposed by McKinney (1923).

The evaluation period, the influence of the number of leaves per genotype and the distribution of the experimental samples to assess resistance by the leaf disk assay were also considered.

\section{MATERIAL AND METHODS}

\section{Plant material}

The leaves of the clones Sca6, ICS1, TSH516 (F 1 of Sca6 $\mathrm{x}$ ICS1) and SIC19 (Forastero susceptibility standard to black pod) and $213 \mathrm{~F}_{2}$ genotypes (Sca6 X ICS1) used for the tests were obtained, respectively, from cacao trees growing in the Active Germplasm Bank and in the greenhouse of the Centro de Pesquisas do Cacau/ Comissão Executiva do Plano da Lavoura Cacaueira (CEPEC/ CEPLAC), in Itabuna, Bahia, Brazil.

The isolate of $P$. palmivora was obtained from the Phytophthora culture collection of the laboratory of Phytophthora (Phytolab) of CEPEC/CEPLAC. The viability and pathogenicity of the isolate was maintained by regular inoculation of young cacao leaves, with subsequent reisolation on selective medium and incubated at $25^{\circ} \mathrm{C}$ in the dark. The zoospore suspension was obtained from $P$. palmivora culture grown on petri dishes with carrot-agar medium, for at least five days. To obtain zoospores, the plates were filled with cold, sterile distilled water and maintained at $4{ }^{\circ} \mathrm{C}$ for 25 minutes and then exposed to room temperature for 20 minutes.

\section{Leaf disk inoculatins}

Inoculations were carried out according to the methodology developed by Nyassé et al. (1995). From each genotype one to three leaves, about two months old, were collected before noon. These leaves were labeled and sent to the Phytolab, where they were cleaned with cotton pads soaked in distilled water and leaf disks (diameter $1.5 \mathrm{~cm}$ ) were cut with a semi-automatic cutter. These disks were laid, with the abaxial leaf surface up, in boxes lined with wet sterilized foam. Each box contained a maximum of 26 cacao genotypes of the $\mathrm{F}_{2}$ population, plus the clones ICS1, Sca6, TSH516 and SIC19, in all trials.

Each disk was inoculated with an aliquot of $0.2 \mathrm{~mL}$ of a $P$. palmivora zoospore suspension at a concentration of $3 \times 10^{5} \mathrm{~mL}^{-1}$ zoospores, calculated using a Neubauer chamber. The boxes were closed to maintain the relative humidity close to $100 \%$ and avoid any contact of the disks with light sources, maintaining temperatures between 24 and $26^{\circ} \mathrm{C}$. The symptoms were assessed on a $0-5$ scale of the infection level (IL) proposed by Nyassé et al. (1995), where $0=$ no symptoms, $1=$ isolated small brown or dark brown spots, 2 = small brown spots with few connections between them, 3 = brown spots forming coalescing lesions of intermediate size, $4=$ large coalescing lesions with light or dark brown points and $5=$ large brown uniform lesions covering the whole leaf disk.

\section{Days of incubation until infection evaluation}

To verify whether the reaction of cacao genotypes to $P$. palmivora are influenced by different intervals of days after inoculation, a leaf disk assay was arranged in a completely randomized design consisting of four cacao clones (Sca6, ICS1, TSH516 and SIC19) with 120 replications (inoculated leaf disks) per clone. The symptoms were assessed five and seven days after inoculation, by adopting the above IL scale (Nyassé et al. 1995). The results were subjected to analysis of variance and $t$ test comparison of means, at $\alpha=0.05$. 


\section{Influence of the number of leaves tested per genotype and distribution of experimental treatments}

To assess the possible influence of disks taken from a single leaf or from several leaves of the same genotype (young leaves were chosen for sampling) and the distribution of the treatments in different boxes, an experiment (leaf disk assay) was set up in a randomized block design, comprising two blocks (boxes), four genotypes (Sca6, ICS1, TSH516 and SIC 19), three treatments (leaves) and 10 replications (replication $=$ leaf disk), totaling 120 leaf disks per box. The symptoms were assessed after seven days of incubation, using the IL scale proposed by Nyassé et al. (1995). The values were analyzed by ANOVA and coefficient of variation, at $\alpha=0.05$.

\section{Gradient resistance of cacao to Phytophthora palmivora}

The resistance gradient of $P$. palmivora in a segregating $\mathrm{F}_{2}$ cacao population (Sca6 x ISC1) was characterized by the leaf disk assay in a randomized design, consisting of 217 genotypes (213 genotypes of the $\mathrm{F}_{2}$ population, and the clones Sca6, ICS1, TSH516 and SIC19 and 12 replications (replication $=$ mean observation of five leaf disks). These disks were obtained and inoculated as described above, and five disks per genotype placed in each box. The symptoms were assessed seven days after inoculation. From the values obtained from the symptomatology classification based on the IL scale (Nyassé et al. 1995) the disease index (DI, ranging from 0 to 1), proposed by Mckinney (1923), was calculated as: DI $=\Sigma I L \cdot L D / T N L D . H I L ;$ where $\mathrm{IL}=$ infection level estimated for each leaf disk; $\mathrm{LD}=$ number of leaf disks per IL; TNLD = total number of leaf disks; and HIL = highest infection level on the scale. These data were subjected to analysis of variance and mean comparison tests and coefficient of variation, at $\alpha=0.05$.

\section{Statistical analysis}

In addition to the above test procedures, descriptive statistics were performed (mean, median, standard deviation, standard error and coefficient of variation) and the normality of the data measured by the Lilliefors test. When necessary, data were transformed according to the Box-Cox test (Box and Cox 1964). For these tests the softwares BioEstat 5.0 (Ayres et al. 2005) and SASM-Agri 3.2.4 (Canteri et al. 2001) were used.

\section{RESULTS AND DISCUSSION}

\section{Days of incubation until infection evaluation}

The symptom severity differed significantly among cacao clones in the tests five and seven days after inoculation with a zoospore suspension of P. palmivora $(\mathrm{p}<0.001)$ (Table 1). The $\mathrm{F}$ values were discrepant regarding the IL ( $\mathrm{F}=92.6$ and 251.9, after five and seven days, respectively); the period of seven days with the highest value of $\mathrm{F}$ was used for the experiments. The results of the test of means between the symptom severity of the cacao clones were similar between values measured five and

Table 1. ANOVA between severity levels obtained by evaluating the symptoms of four cacao clones (Sca6, ICS1, TSH516 and SIC19),

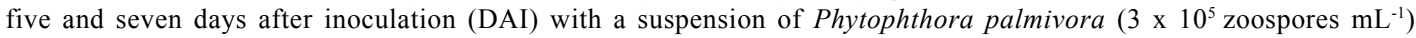

\begin{tabular}{ccrrrr}
\hline Time until evaluation & Sources of variation & df & SS & \multicolumn{1}{c}{ MS } & F $(\boldsymbol{p}$ value $)$ \\
\hline \multirow{2}{*}{ 5 DAI } & Clones & 3 & 275.640 & 91.88 & $92.6(<0.001)$ \\
& Error & 476 & 471.842 & 0.99 & $251.9(<0.001)$ \\
& Clones & 3 & 448.206 & 149.40 & 0.59 \\
\hline
\end{tabular}

Table 2. Comparison of means by the Tukey test $(\alpha=0.05)$ between severity levels obtained for pairs of clones among the four cacao clones (Sca6, ICS1, TSH516 and SIC19) inoculated, five and seven days after inoculation with a suspension of Phytophthora palmivora (3 x $10^{5}$ zoospores $\left.\mathrm{mL}^{-1}\right)$

\begin{tabular}{|c|c|c|c|c|c|c|}
\hline \multirow{2}{*}{ Clone pairs } & \multicolumn{3}{|c|}{5 days after inoculation } & \multicolumn{3}{|c|}{7 days after inoculation } \\
\hline & Difference & MS & ( $p$ value) & Difference & MS & ( $p$ value) \\
\hline Sca6andICS1 & 2.1417 & 23.5639 & $<0.01$ & 2.6750 & 38.0512 & $<0.01$ \\
\hline Sca6andTSH516 & 1.0750 & 11.8278 & $<0.01$ & 1.7167 & 24.4192 & $<0.01$ \\
\hline Sca6andSIC19 & 1.1417 & 12.5613 & $<0.01$ & 1.7500 & 24.8933 & $<0.01$ \\
\hline ICS1andTSH516 & 1.0667 & 11.7361 & $<0.01$ & 0.9583 & 13.6321 & $<0.01$ \\
\hline ICS1andSIC19 & 1.0000 & 11.0026 & $<0.01$ & 0.9250 & 13.1579 & $<0.01$ \\
\hline TSH516andSIC19 & 0.0667 & 0.7335 & ns & 0.0333 & 0.4742 & ns \\
\hline
\end{tabular}


seven days after inoculation with P. palmivora (Table 2), suggesting a similar clone response to the pathogen in both periods. However, the mathematical difference between the symptom severity of the clones Sca6 and ICS1, with contrasting resistance, was more pronounced in the data obtained after seven (2.675) than after five days (2.141).

These data are consistent with previous studies (Nyassé et al. 1995, Tahi et al. 2006a, Luz et al. 2006), in which the evaluations were performed three, five and seven days after inoculation. In these studies, the authors observed that three days of incubation are not sufficient to accurately separate the resistant from the susceptible genotypes, while after five and especially after seven days the IL tends to becomes stable. Although seven days of incubation is not the minimum time required for evaluation, evaluations were performed after this period in some studies (Nyassé et al. 1995, Tahi et al. 2006b, Paulin et al. 2008), based on the explanation that this is the most efficient way to detect the genetic variability for resistance to black pod in cacao.

\section{Influence of the number of leaves tested per genotype and distribution of experimental treatments}

No variation was observed in the severity level of infection by P. palmivora on different leaves per clone from which the disks were collected for inoculation, nor in the reaction of the clones arranged in different boxes (Figure 1). The means and extremes values analyzed and standard deviations did not differ significantly, and no significant differences were observed in these evaluations between the boxes ( $\mathrm{p}=0.56$ and 0.41 ; Krukal-Wallis and Bootstrap with 10,000 re-samplings, respectively); and between the leaves $(\mathrm{p}=0.08$ and 0.21 , Wilcoxon and Bootstrap with 10,000 re-samplings, respectively) (data not shown).

The absence of significant variation due to the distribution of disks of the same genotype in different boxes (four boxes, with five disks of each assessed genotype) indicates the reliability of the leaf disk assay to evaluate the resistance of cocoa genotypes to black pod. This result is consistent with Pokou et al. (2008), who observed that large enough boxes to hold an adequate number of genotypes for serial inoculation are not always available; on average, 20 leaf disks per genotype are tested, and sometimes four boxes are required to organize the leaf disks.

The lack of significant effect observed when using a single leaf or different leaves of the same genotype (Figure 1B) indicates that one factor that could limit the use of the leaf disk assay, which is the availability of at least five leaves suitable for inoculation at standardized age (approximately 2 months) (Tahi et al. 2006a), may be reconsidered, at least under extreme conditions. In such
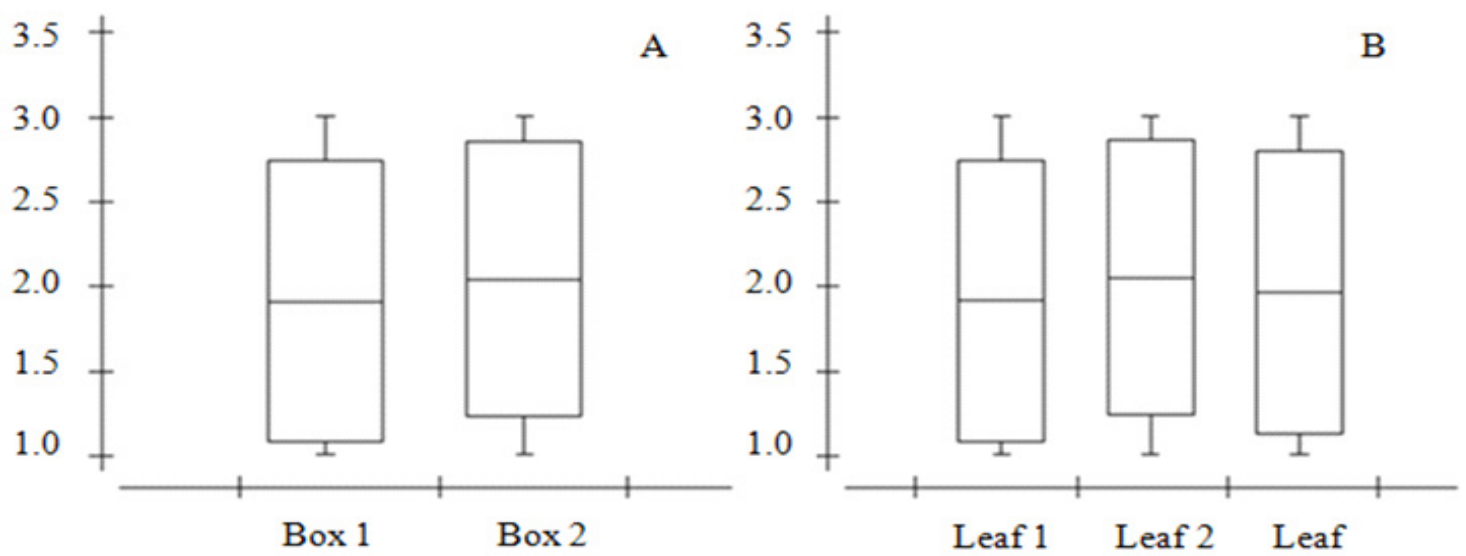

Figure 1. Box-plot diagram of mean, extreme standard deviation values for the black pod severity levels of cacao clones (Sca6, ICS1, TSH516 and SIC19) distributed in different boxes (A), from different leaves of the same genotype (B). The evaluations were performed seven days after inoculation with suspension of Phytophthora palmivora $\left(3 \times 10^{5}\right.$ zoospores $\left.\mathrm{mL}^{-1}\right)$. 
cases, a single leaf without any injuries or signs of infection, in good physiological condition and appropriate age, can be used for testing.

\section{Resistance gradient of cacao to Phytophthora palmivora}

Symptoms were observed on all genotypes seven days after inoculation, showing that none of them was immune to the pathogen. Moreover, there was wide variation in the reaction of the evaluated plant material, suggesting a resistance gradient (DI ranging from 0.23 to 0.94) (Table 3). The variance analysis based on the DI values obtained in the leaf disk assay, indicated significant differences $(\mathrm{p}<0.01)$, confirming the differentiated response of these genotypes to P. palmivora. The observed variation for resistance among cacao genotypes from the $\mathrm{F}_{2}$ population (Sca6 x ICS1) (Table 3), was partly explained by the fact that the resistance to black pod of their parents differed greatly, i.e., clone Sca6 is considered resistant (Tahi et al. 2000, Bartley 2005), while clone ICS1 is considered susceptible to the disease (Paulin et al. 2008).

The analysis based on the mean comparison test $(p<0.01$; Scott-Knott) allowed the grouping of genotypes into five homogenous and statistically different groups (Table 3). In this experiment, the infection level of clone Sca6 was the lowest (0.23) (Figure 2, Table 3). Seventeen genotypes of the assessed progeny with severity levels from 0.46 to 0.55 (cluster B) were deemed appropriate for cocoa breeding programs. Cluster $\mathrm{C}$ had the highest number of genotypes with intermediate resistance (severity level 0.56 - 0.65). The distribution of clones Sca6, ICS1, TSH516 and SIC19 in the groups based on the means of the ScottKnott test, evidences the efficiency of clone Sca6, parent of the $\mathrm{F}_{2}$ population, as resistance standard (Table 3, Figure 2). The ICS1clone, parent of the population and susceptibility standard (Yamada et al. 2009), and SIC19, considered a susceptibility standard, were assigned to the group of intermediate resistance (cluster C). In the studied population, the susceptibility to the pathogen of 82 genotypes in the clusters D and E was greater than of the two control clones (ICS1 and SIC19) (Table 3).

The level of infection observed in clone Sca6 (DI = 0.23 ) is equivalent to the level of infection of 1.23 obtained by averaging the observed values using the IL scale (data not shown). According to the classification criterion used

Table 3. Description of the univariate clustering of 217 cacao genotypes ${ }^{1}$ assessed for resistance to Phytophthora palmivora by the leafdisk test and by the disease index proposed by Mckinney (1923)

\begin{tabular}{ccccc}
\hline Cluster $^{2}$ & No. of genotypes & Mean of genotypes & Extreme values & Range \\
\hline A & 1 & 0.23 & - & 0 \\
B & 17 & 0.52 & 0.46 a 0.55 & 0.09 \\
C & 117 & 0.60 & 0.56 a 0.65 & 0.09 \\
D & 68 & 0.70 & 0.66 a 0.76 & 0.10 \\
E & 14 & 0.82 & 0.77 a 0.94 & 0.17 \\
\hline
\end{tabular}

${ }^{1}$ The 217 cacao genotypes consisted of 213 cacao trees of a $F_{2}$ population of Sca6 x ICS1 and four cacao clones: Sca6, ICS1, TSH516 $\left(\mathrm{F}_{1}\right.$ de Sca6 x ICS1) and SIC19 (susceptibility standard to P. palmivora); ${ }^{2}$ The mean values of each cluster differ statistically ( $\mathrm{p}<0.01$; Scott-Knott test).

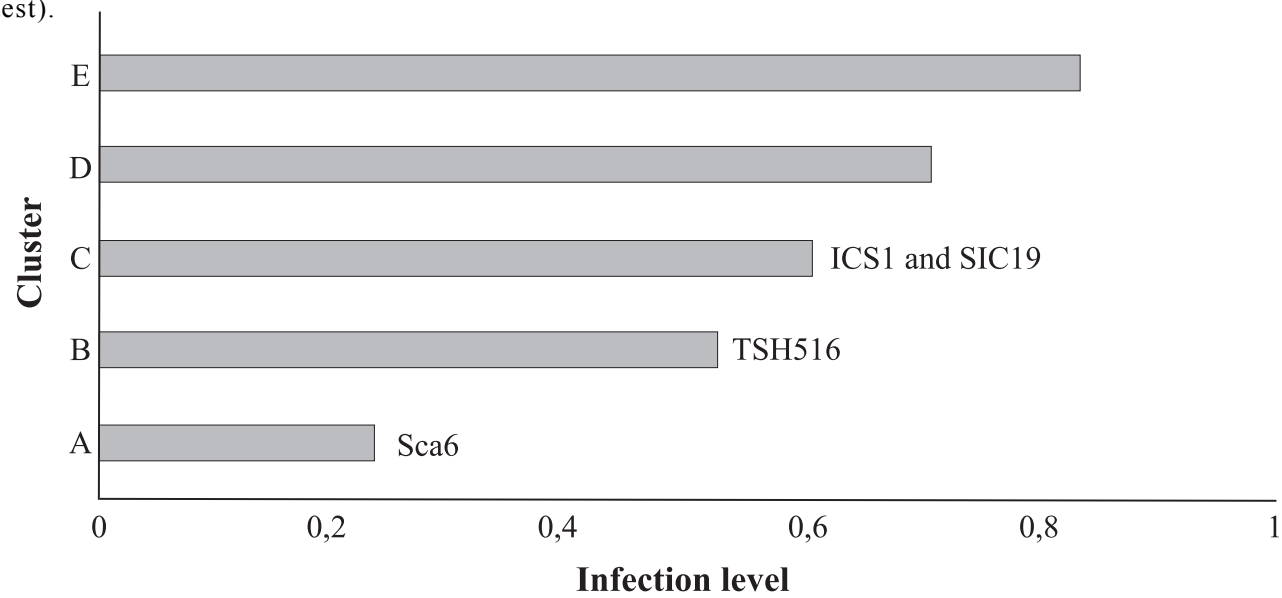

Figure 2. Location of cacao clones assessed for resistance to Phytophthora palmivora, by the leaf-disk test. The infection level was determined by the disease index (McKinney 1923), which had been calculated based on the grade scale proposed by Nyassé et al. (1995). For the description of clusters and clones see Table 3. 
by Paulin et al. (2008), which is based on the grade scale, Sca6 is the only genotype in this study that is resistant (1 $<$ score $\leq 2)$. Also according to this criterion, the genotypes of the progeny studied were classified as follows: six moderately resistant genotypes $(2 \leq$ score $\leq 2.5)$ including clone TSH516 in $\mathrm{F}_{1}(\mathrm{DI}=0.51, \mathrm{IL}=2.4), 170$ susceptible $(2.5<$ score $\leq 3.5)$ including control SIC19 and the parent $\mathrm{ICS} 1$ (DI $=0.59$ and $0.61, \mathrm{IL}=2.7$ and 3.0, respectively) and 40 highly susceptible genotypes $(3.5<$ score $<5)$. The genotypes of cluster B are useful for future breeding programs targeting the associated increase of resistance and yield variables, corroborating the use of the leaf disk assay for characterizations of the cacao vs. P. palmivora pathosystem (Nyassé et al. 2002). Another relevant result of this study was the identification of genotypes with higher susceptibility levels than clone SIC19 (susceptible standard) (Figure 2, Table 3), which may be useful as controls in tests involving the evaluation of cocoa trees for black-pod resistance. Also noteworthy is that the genetic variability found indicates the use of $\mathrm{F}_{2}$ (Sca6 $\mathrm{x}$ ICS1) for genetic mapping studies to identify quantitative trait loci (QTLs) related to P. palmivora resistance.

\section{ACKNOWLEDGEMENTS}

The authors thank the National Council of Scientific and Technological Development (CNPq) for the fellowship of C.B.M. Cerqueira-Silva and for the research grant of E.D.M.N. Luz; the Fundação de Amparo a Pesquisa do Estado da Bahia for the fellowship of E.S.L. Santos; the CEPEC/CEPLAC for granting permission to use the laboratories and for the agreement with $\mathrm{CFC} / \mathrm{ICCO} /$

\title{
Gradiente de resistência à podridão-parda e seleção de cacaueiro usando teste de disco foliar
}

\begin{abstract}
RESUMO - Neste estudo, objetivando caracterizar o gradiente de resistência à podridão-parda em 217 genótipos de cacaueiro, foi realizado experimento de inoculação em disco foliar. Os parâmetros intervalo de tempo para avaliação, número de folhas avaliadas por genótipo e distribuição dos tratamentos experimentais foram avaliados. Observou-se diferença significativa entre os genótipos, possibilitando a separação dos mesmos em cinco grupos homogêneos $(p<0,01)$. Para as avaliações do teste de discos foliares, realizadas cinco e sete dias após a inoculação, foi observado maior valor de F aos sete dias, separando melhor os genótipos resistentes dos susceptíveis. Não houve diferença entre os clones quanto a utilização de mais de uma caixa para acomodação dos genótipos $(p=0,56)$ e a utilização de folhas diferentes do mesmo genótipo $(p=0,08)$. O gradiente de resistência observado na população indica que a mesma apresenta variabilidade desejada para fins de mapeamento e melhoramento genético do cacaueiro.
\end{abstract}

Palavras-chave: mapeamento genético, melhoramento genético, indice de doença, Phytophthora palmivora, Theobroma cacao.

Bioversity for financing part of the research.

\section{REFERENCES}

Akinnifesi TA, Asubiojo OI and Amusan AA (2006) Effects of fungicide residues on the physico-chemical characteristics of soils of a major cocoa-producing area of Nigeria. Science of the Total Environment 366: 876-879.

Ayres M, Ayres Jr M, Ayres DL and Santos AAS (2005) BioStat 4.0. Aplicações estatísticas nas áreas das ciências biomédicas. Instituto Mamirauá, Belém, 324p.

Bartley BGD (2005) The genetic diversity of cacao and its utilization. CAB International, Wallingford, 341p.

Bowers JH, Bailey BA, Hebbar PK, Sanogo S and Lumsden RD (2001) The impact of plant diseases on world chocolate production. Available at $<$ http:// www.plantmanagementnetwork.org/pub/php/review/cacao> Accessed on 10 Jan, 2009.

Box GEP and Cox DR (1964) An analysis of transformations. Journal of the Royal Statistical Society 26: 211-252.

Canteri MG, Althaus RA, Virgens Filho JS, Giglioti EA and Godoy CV (2001) SASM-Agri: sistema para análise e separação de médias em experimentos agrícolas pelos métodos ScottKnott, Tukey e Duncan. Revista Brasileira de Agrocomputação 1: 18-24.

Cerqueira-Silva CBM, Moreira CN, Figueira AR, Corrêa RX and Oliveira AC (2008) Detection of a resistance gradient to Passion fruit woodiness virus and selection of 'yellow' passion fruit plants under field conditions. Genetics and Molecular Research 7: 1209-1216.

Czermainski ABC (1999) Generalização de um índice de intensidade de infecção em experimentos de avaliação de 
doenças em plantas. Pesquisa Agropecuária Brasileira 34: $1545-1555$.

Dias LAS (2001) Origem e dispersão de Theobroma cacao L.: um novo cenário. In Dias LAS (ed.) Melhoramento genético do cacaueiro. Funape, Viçosa, p. 81-127.

Faleiro FG, Lopes UV, Yamada MM, Melo GRP, Monteiro WR, Pires JL, Rocha JB, Bahia RCS, Gomes LMC, Araújo IS and Faleiro ASG (2004) Genetic diversity of cacao accessions selected for resistance to witches' broom based on RAPD markers. Crop Breeding and Applied Biotechnology 4: $12-17$.

Iwaro AD, Sreenivasan TN, Butler DR and Umaharan P (2000) Rapid screening for Phytophthora pod rot resistance by means of detached pod inoculation. In Eskes AB, Engels JMM and Lass RA (eds.) Proceedings of the CFC/ICCO/IPGRI Project Workshop. IPIGRI, Montpellier, p. 109-113.

Luz EDMN and Silva SDVM (2001) Podridão-parda dos frutos, cancro e outras doenças causadas por Phytophthora no cacaueiro. In Luz EDMN, Santos AF, Matsuoka K and Bezerra JL (eds.) Doenças causadas por Phytophthora no Brasil. Livraria Rural, Campinas, p. 175-265.

Luz EDMN, Paim MCA, Silva SDVM, Pires JL, Santos Filho LP and Monteiro WR (2006) Correlation of cacao clones' reactions to different species of Phytophthora. In Eskes AB and Efron $\mathrm{Y}$ (eds.) Global approaches to cocoa germplasm utilization and conservation. CFC/ICCO/IPGRI, Amsterdam, p. 132-136.

Mckinny HH (1923) Influence of soil, temperature and moisture on infection of wheat seedlings by Helminthosporium sativum. Journal of Agricultural Research 26: 195-217.

Nyassé S, Cilas C, Herail C and Blaha G (1995) Leaf inoculation as an early screening test cacao (Theobroma cacao L.) resistance to Phytophthora black pod disease. Crop Protection 14: 657663.

Nyassé S, Despréaux D and Cilas C (2002) Validity of a leaf inoculation test to assess the resistance to Phytophthora megakarya in a cocoa (Theobroma cacao L.) diallel mating design. Euphytica 123: 395-399.

Nyassé S, Efombagn MIB and Eskes AB (2003) Selection for resistance to black pod disease and yield gains prediction by use of selected cocoa varieties in Cameroon. Plant Genetic Resources 1: 157-160.

Nyassé S, Efombagn MIB, Kébé BI, Tahi M, Despréaux D and Cilas C (2006) Integrated management of Phytophthora diseases on cocoa (Theobroma cacao L): impact of plant breeding on pod rot incidence. Crop Protection 26: 40-45.

Paulin D, Ducamp M and Lachenaud P (2008) New sources of resistance to Phytophthora megakarya identified in wild cocoa tree populations of French Guiana. Crop Protection 27: 11431147.

Pokou ND, N'Goran JAK, Kébé I, Eskes A, Tahi M and Sangaré A (2008) Levels of resistance to Phytophthora pod rot in cocoa accessions selected on-farm in Côte d'Ivoire. Crop Protection 27: 302-309.

Santos ESL, Cerqueira-Silva CBM, Clément DPL and Luz EDMN (2009) Identificação de resistência genética do cacaueiro à podridão-parda. Pesquisa Agropecuária Brasileira 44: 413416.

Tahi GM, Kébé BI, Eskes AB, Ouattara S, Sangaré A and Mondeil F (2000) Rapid screening of cacao genotypes for field resistance to Phytophthora palmivora using leaves, twigs and roots. European Journal of Plant Pathology 106: 87-94.

Tahi GM, Kébé BI, Sangare A, Mondeil F, Cilas C and Eskes AB (2006a) Foliar resistance of cacao (Theobroma cacao) to Phytophthora palmivora as an indicator of pod resistance in the field: interaction of cacao genotype, leaf age and duration of incubation. Plant Pathology 55: 776-82.

Tahi GM, Kébé BI, N'Goran JAK, Sangaré A, Mondeil F, Cilas C and Eskes AB (2006b) Expected selection efficiency for resistance to cacao pod rot (Phytophthora palmivora) comparing leaf disc inoculations with field observations. Euphytica 149: 35-44.

Tan GY and Tan WK (1990) Additive inheritance of resistance to pod rot caused by Phytophthorapalmivorain cacao. Theoretical and Applied Genetics 80: 258-264.

Word Cocoa Foundation (2008) Cocoa production statistics. Available at $<\mathrm{http} / / / \mathrm{www}$.chocolateandcocoa.org $>$ Accessed on 20 Dec., 2008.

Yamada MM, Faleiro FG, Flores AB, Lopes UV, Pires JL, Corrêa RX and Santos RF (2009) Microsatellite diversity and heterozygosity of parents of a cocoa breeding population. Crop Breeding and Applied Biotechnology 9: 17-22. 